\title{
The Impact of Testicular Cancer on Fertility - Literature Review
}

\author{
Vasilica Minciuna', Octavian Cretu', Dan Spinu', Dragos Marcu², Ovidiu Bratu2,3
}

\begin{abstract}
This article is a literature review that emphasis the impact of testicular cancer on fertility and current management to prevent and treat infertility. Foreign literature has a lot of multicenter prospective longitudinal and retrospective studies of negative effects on fertility in men with teticular cancer. Testicular cancer has a negative impact on fertility because of its high incidence (7.52 cases per 100000 of the population) in young men with age between 15 and 35 years old. At the time they discover they have testicular cancer, many man have few or no sperm. In addition, all of the treatment for testicular cancer can directly or indirectly cause fetility problems. Sperm abnormatilies are frequent in men with testicular cancer. Patiens who underwent chemotherapy with bleomicin, doxorubicin, cisplatin or radiotherapy have a high risk to develop sperm aneuploidy. Genetic and psychological counseling should be done before choosing any treatment for testicular cancer. Sperm and embryo cryopreservation should be considered as early as possible before any treatement for testicular cancer.
\end{abstract}

Keywords: fertility, testicular cancer, sperm aneuploidy, sperm cryopreservation.

\section{Rezumat}

Articolul de față își propune să evidențieze pe de o parte impactul cancerului testicular asupra fertilității, iar pe de altă parte managementul de prevenție si tratament al infertilității. Literatura de specialitate din străinătate beneficiază de o perspectivă multicentrică, dar și de studii retrospective referitoare la efectele negative pe care cancerul testicular le are asupra fertilității la bărbați. Cancerul testicular are un impact negativ asupra fertilității din cauza incidenței sale ridicate (7,52 de cazuri la 100.000 de locuitori) în rândul bărbaților tineri, cu vârste cuprinse între 15 și 35 de ani. În momentul în care cancerul testicular este diagnosticat, mulți dintre aceștia mai au foarte puțin lichid seminal, unii chiar delor. Suplimentar, toate tipurile de tratament pentru cancerul testicular pot cauza direct sau indirect probleme de fertilitate. Anomaliile la nivelul lichidului seminal sunt frecvente la bărbații cu cancer testicular. Pacienții care au fost supuși chimioterapiei cu bleomicină, doxorubicină, cisplatin sau radioterapiei au un risc mai mare de a dezvolta aneuploidie seminală. Consilierea psihologică și cea genetică ar trebui luate în considerare înainte de a alege tratatmentul pentru cancerul testicular. Criogenarea spermei și a embrionului ar trebui, de asemenea, luate în considerare cât mai devreme cu putință înainte de a începe orice tratament pentru patologia ce face subiectul acestei lucrări.

Cuvinte cheie: fertilitate, cancer testicular, aneuploidie seminală, criogenarea spermei.

1 Emergency County Hospital, Slobozia, Romania

${ }^{2}$ Clinic of Urology, „Dr. Carol Davila” Central Military Emergency

University Hospital, Bucharest, Romania

3 "Carol Davila" University of Medicine and Pharmacy, Bucharest,

Romania
Corresponding author.

Octavian Cretu, Emergency County Hospital, Slobozia, Romania. 
Testicular cancer has an increased incidence among young males (15-35 years old $)^{1}$.

The incidence in testicular cancer for this category of patients is quite high, 7.52 new cases for 100000 people. The predominant histopathological subtypes among fertile-aged young males are embryonal carcinoma and teratocarcinoma ${ }^{1}$.

The mortality rate has dropped dramatically from $50 \%$ in the late 1970 's to less than $5 \%$ in the last years, testicular cancer being considered one of the few cancers that can be cured by various treatment modalities, depending on its stage ${ }^{1}$.

In the US and UK, it represents the most common type of cancer among males aged 20-34 and it occupies the second place among males aged $35-40^{1}$.

Testicular cancer has negative consequences on fertility for the following reasons:

- It has an increased incidence among young men $^{2}$;

- Many men have oligospermia at the time of diagnosis $^{2}$;

- All treatments applied in testicular cancer (orchiectomy, polichemotherapy, radiotherapy, RPLND) affect fertility in direct or indirect ways. Those treatments can lower hormone levels and also lower the chances to conceive a child. Even after orchiectomy, the healthy testicle can produce a sufficient amount of sperm to ensure a normal testosterone level ${ }^{3,4}$.

\section{CONNECTIONS BETWEEN TESTICULAR CANCER AND ORCHIECTOMY}

For most patients, unilateral orchiectomy does not involve fertility problems ${ }^{4}$.

In some cases, orchiectomy is applied so fast in order to remove the tumor that the fertility problem is not considered in young men $^{3}$.

In the US (Memorial Sloan Kettering Cancer Center, New York, NY), Herr et al. studied long-term paternity for patients diagnosed with testicular cancer stage I, which had orchiectomy as the only treatment $\operatorname{method}^{5,6}$.

$65 \%$ of the participants had a baby in the first 5 years after the intervention ${ }^{6}$.

Psychological counseling and sperm cryopreservation must be taken into account, especially if the testicle that has not been operated presents atrophy or cryptorchidism ${ }^{3,4}$.

\section{FERTILITY AND RPLND}

In testicular cancer, RPLND (retroperitoneal lymph node dissection) represents the standard procedure to remove the retroperitoneal lymph nodes in nonseminomatous testicular tumors stage $\mathrm{I}$ and $\mathrm{II}^{7,8}$.

Unfortunately, one of the side effects of this method is retrograde ejaculation, consequence of sympathetic nerves injury, which are implied in ejaculation process ${ }^{7}$.

Modified retroperitoneal lymph nodes dissection was a new method introduces in the early 80's. This method was applicable in incipient stages of cancer and it involves a lymphatic dissection limited in certain territories, in order not to interfere with sympathetic innervation. This method prevented retrograd ejaculation in approximately $70 \%$ of the cases ${ }^{7,8}$.

In the early 1990s was introduced a new technique which prevented retrograd ejaculation in $100 \%$ of the cases. This method was based on rigurous dissection of lymphatic tissue and sympathetic nerves ${ }^{7}$.

If surgery is performed after chemotherapy, it has fewer chances to succeed because chemotherapy may cause adhesions and alterations in the structure of lymphonodular system ${ }^{7}$.

Administration of some medicines like ephedrine derivatives or pseudoephedrine, imipramine or clorpheniramine can temporary prevent retrograde ejaculation until conceiving a child ${ }^{7}$.

If this is not possible and sympathetic innervation was severely injured, retrograde ejaculation is irreversible ${ }^{7}$.

Even if retrograde ejaculation occurs, this is not equivalent to sterility. Sperm can be collected from the bladder and then be used as a product of conception in artificial insemination ${ }^{7,8}$.

\section{FERTILITY AFTER CHEMOTHERAPY}

Chemotherapy is successfully applied in advanced testicular cancers.

Its efficiency is due to destroying germ cells. The disadvantage is that sperm is produced by this germ cells and its quantity and quality decrease considerably as a result of chemotherapy?.

In some cases azoospermia is irreversible. However, in $50 \%$ of the cases, the amount of sperm increases in 24-36 months after chemotherapic treatment is over'.

The good quality of sperm is very important before applying the treatment, because it influences the chances of reversibility of postchemotherapy azoospermia ${ }^{9}$.

Surely, the number of cytostatic cures has an in- 
fluence on fertility; a large number of chemotherapy treatments implies a higher risk of sterility ${ }^{9}$.

Approximate $70 \%$ of the patients diagnosed with testicular cancer who received a cytostatic treatment can conceive a baby after 2-3 years after treatment is over'.

\section{FERTILITY AFTER RADIOTHERAPY}

Radiotherapy represents the method of choice in testicular seminoma, ensuring a tumor control rate of $95 \%{ }^{10}$.

Seminomas are rarely found in young population; they are assigned to the third age. Testicular irradiation with approximate $200 \mathrm{rad}$ causes complete sterility and it is applied in case of in situ carcinoma as the unique treatment method. In this case, sperm cryopreservation should be considered before applying radiotherapy ${ }^{10}$.

If radiotherapy is used as an adjuvant method, the radiation dose is $60 \mathrm{rad}$. Doses greater than 100-200 $\mathrm{rad}$ can produce oligospermia that is reversible ${ }^{10}$.

A multicenter study on 488 patients with testicular cancer, conducted in France (Huighe et all in article "Fertility after testicular cancer treatment") between 1979 and 1999 concludes that radiotherapy has a more pronounced negative effect on fertility that chemotherapy. Published statistics indicated a 30\% decrease in fertility of patients with testicular cancer after chemotherapy and radiotherapy ${ }^{11}$.

Another multicenter study conducted in France by River and colab., entitled "Spermatic aneuploidy after testicular cancer treatment" underlines the importance of genetic counseling regarding the high risk of sperm aneuploidy after radiotherapy and chemotherapy ${ }^{10}$. Aneuploidy is a major cause of the development of some fetal genetic syndromes, such as Down syndro$\mathrm{me}^{12}$. Also, it is important to delay the conceiving of a baby for 12 months for radiotherapy and more than 24 months for chemotherapy ${ }^{12}$.

\section{FERTILITY AND CRYOPRESERVATION OF SPERM}

Most multicentre studies recommend sperm cryopreservation before applying any treatment in testicular cancer. It represents an efficient method in case of unpleasant side effects on fertility after surgery or radiotherapy and chemotherapy ${ }^{10}$.

Surely this method increases the patient's psychological comfort and stabilizes the couple's relationship.

In Japan, Sado and collaborators conducted a study of 111 men diagnosed with different types of cancer, whose sperm was cryopreserved chargeless. All men included in the study responded to a questionnaire containing questions about fertility, the desire to have a child, worries about the side effects of treatments and quality of life ${ }^{13}$.

The findings of the study highlighted the positive effects of sperm cryopreservation on patients' perception of cancer. They have shown increased self-esteem and psychic comfort that allowed them to get more easily over cytostatic therapy or radiotherapy ${ }^{13,14}$.

Young patients diagnosed with cancer are often worried about the risk of lowering fertility due to the treatment. Many of those who beat cancer want a baby in the future and some of them even consider the possibility of adopting a child ${ }^{13}$.

Unfortunately, in Romania, the preservation of sperm in a bank has extremely high costs, so the infertility rate remains high, due to the financial impossibility to perform this procedure.

American Oncological Society recommends urologists and oncologists to inform the patient of its fertility risks before performing any medical procedure ${ }^{15}$.

Researchers from the University of Pennsylvania have accessed the Medline database and Cochrane Medical Virtual Library in order to develop a medical review of the literature published between March 2006 and January $2013^{15}$.

Researchers found 222 new publications, of which 18 randomized clinical trials, numerous observational studies, cohort studies and clinical cases that met the criteria for inclusion in the review. Their conclusion highlighted the importance of informing the patient and, more than that, guidance to a fertility specialist before surgical treatments, polychemotherapic treatments or radiotherapy ${ }^{15}$.

\section{CONCLUSIONS}

Testicular cancer affects fertility through applied treatment methods: polychemotherapy, bilateral orchiectomy in case of bilateral testicular tumor, radiotherapy, retroperitoneal lymph nodes dissection.

Most patients can conceive a child in the first 5 years after the end of radiotherapy or chemotherapy.

Before applying any treatment, patients must sign an informed consent about the potential risks of lowering fertility, occurrence of chromosomal anomalies such as sperm aneuploidy, in the first 12-24 months after the end of chemotherapy or radiotherapy. They also need to be advised to delay the moment of conceiving a child up to 12-24 months from the treatment ending, depen- 
ding on the irradiation dose or the number of cytostatic cycles.

\section{References}

1. Albers (Chair) P, Albrecht W, Algaba F, et al. Guidelines on Testicular Cancer. European Association of Urology. Mar 2012; 36(3):127-145.

2. Oliver RT, Mason MD, Mead GM et al. Radiotherapy versus single-dose carboplatin in adjuvant treatment of stage I seminoma: a randomised trial. Lancet 2005; 366: 293-300.

3. Donohue JP, Foster RS. Retroperitoneal lymphadenectomy in staging and treatment. The development of nerve-sparing techniques. Urol Clin North Am. 1998;25:461-468.

4. Travis LB, Fossa, Schonfeld SJ, McMaster ML, et al. Second cancers among 40,576 testicular cancer patients: focus on long-term survivors. J Nat Cancer Inst. 2005;97:1354-1365.

5. Abouassaly R, Fossa SD, Giwercman A. et al. Sequelae of treatment in long term survivors of testis cancer. European Association. Elsevier. September 2011; 60(3):516-26.

6. Davis BE, Herr HW, Fair WR, Bosl GJ. The management of patients with nonseminomatous germ cell tumors of the testis with serologic disease only after orchiectomy. J Urol. 1994;152:111113.

7. Eggener SE, Carver BS, Sharp DS, Motzer RJ, Bosl GJ, Sheinfeld $J$. Incidence of disease outside modified retroperitoneal lymph node dissection templates in clinical stage I or IIA nonseminomatous germ cell testicular cancer. J Urol. 2007;177:937-942.

8. Schmoll $7 \mathrm{H}$, Jordan $\mathrm{K}$, Huddart $\mathrm{R}$ et al. Tumorile germinale testiculare seminomatoase: Ghidul ESMO de practică clinică pentru diagnosticare, tratament şi urmărire. Journal of Radioterapy and Medical Oncology. 2010; 63: 1-8.
The current management of testicular cancer must include psychological and genetic counseling, as prevention stages of sterility and high emotional impact of the cancer.

9. Cella D, Davis K, Breitbart W, curt G. Cancer related fatigue: prevalence of proposed diagnostic criteria in a United States sample of cancer survivors. Journal Clin Oncol. Jul 15 2001; 19(14):3385-3391.

10. Rives N, Walschaerts $M$, Setif $V$, et al. Sperm aneuploidy after testicular cancer treatment: data from a prospective multicenter study performed within the French Centre d'Etude et de Conservation des Oeufs et du Sperme network. Elsevier March $2017 ; 107: 580-588$.

11. Huyghe E, Matsuda T, Daudin M, et al. Fertility after testicular cancer treatments: results of a large multicenter study. American Cancer Society. Feb 2004; 100: 732-737.

12. Ostrowski KA, Walsh TJ . Infertility with Testicular Cancer. The Urologic Clinics of North America 2015; 42 (3): 409-420.

13. Yu Seob Shin and Hyung Jin Kim. Current Management of Testicular Cancer. Korean Journal Of Urology 2013 jan; 54(1):2-10.

14. Stephanie J. Lee, Leslie R. Schover, Ann H. Partridge, et al. American Society of Clinical Oncology Recommendations on Fertility Preservation in Cancer Patients. Journal of Clinical Oncology. June 2006; 18:2917-2931.

15. Bokemeyer $\mathrm{C}$, Kohrmann $\mathrm{O}$, Tischler $\mathrm{J}$, et al. A randomized trial of cisplatin, etoposide and bleomycin (PEB) versus carboplatin, etoposide and bleomycin (CEB) for patients with 'good-risk' metastatic non-seminomatous germ cell tumors. Ann Oncol. 1996;7:1015-1021. 